Int. J. Morphol.,

27(3):811-817, 2009.

\title{
Esophageal Anatomy of the Llama (Lama glama)
}

\author{
Anatomía del Esófago de la Llama (Lama glama) \\ "Peerapol Sukon; " Karen I. Timm \& **Beth A. Valentine
}

\begin{abstract}
SUKON, P.; TIMM, K. I. \& VALENTINE, B. A. Esophageal anatomy of the Llama (Lama glama). Int. J. Morphol., 27(3):811-817, 2009.

SUMMARY: This study describes gross, microscopic and muscle fiber anatomy of the esophagus of the llama, Lama glama. The esophagus was studied grossly in twenty-five adult llamas and a subset of ten with normal esophageal physiology was used for the microanatomic studies. Esophageal length was $122 \pm 7 \mathrm{~cm}$ with two-thirds of the length in the neck and the remainder in the thorax, consistent with the long neck of the llama. Esophageal diameter increased steadily from $2.5 \pm 0.3 \mathrm{~cm}$ in the cranial cervical region to 3.9 $\pm 0.8 \mathrm{~cm}$ in the caudal thoracic region. The mucosal epithelium was keratinized stratified squamous and there were abundant submucosal glands throughout the esophagus. The entire muscularis of the esophagus was striated muscle in two general layers but also with a somewhat random orientation of fibers. The tunica muscularis steadily increased in thickness from $3.43 \pm 0.30 \mathrm{~mm}$ in the cranial cervical region to $4.39 \pm 0.39 \mathrm{~mm}$ in the middle thoracic region. In the llama Type 2 muscle fibers predominated in the esophageal musculature, with the percentage of Type 1 fibers increasing from $1 \%$ cranially to $33 \%$ in the caudal thoracic region of the esophagus. This study of the normal llama esophagus enhances our knowledge of this species and provides the basis for future study of pathological conditions of the esophagus.
\end{abstract}

KEY WORDS: Llama; Esophagus; Gross anatomy; Microscopic anatomy; Muscle fiber type.

\section{INTRODUCTION}

The South American camelids, llamas, alpacas, vicuñas and guanacos, are closely related to the true camels. The anatomy of the normal esophagus of the llama (Lama glama) has not been thoroughly described. Studies on the anatomy of the digestive tract (Vallenas et al., 1971) do not include the esophagus. Studies of pathology of the llama esophagus, specifically megaesophagus, include some information on the anatomy of the esophagus (Butt et al., 2001; Belknap, 1994; Smith, 1989; Watrous et al., 1995). The gross course of the esophagus through the neck and thorax of the dromedary camel has been described (Smuts \& Bezuidenhout, 1987), as has some of the microanatomy of the camel esophagus (Dellman et al., 1968; Jamdar \& Ema, 1982).

Esophageal anatomic differences among species reflect phylogenetic adaptation for different foodstuffs consumed by the different species and behavioral adaptations. As the llama is a cud-chewing animal that eats harsh forage in the Andean altiplano (highlands), it is hypothesized that the esophageal musculature is striated throughout, the epithelium is heavily keratinized and there are prominent submucosal glands. This study describes the gross, microscopic and muscle fiber type anatomy of the llama esophagus.

\section{MATERIAL AND METHOD}

Animals. Ten llamas (6 females and 4 castrated males) with normal esophageal function as determined in the esophageal physiology study (Beuthanasia-D Special, Schering-Plough Animal Health Corp, Union, NJ), were used for the gross and microscopic anatomic studies. An additional 15 clinically normal animals from the Camelid Research Herd of the

\footnotetext{
* Department of Anatomy, Faculty of Veterinary Medicine, Khon Kaen University, Khon Kaen, Thailand, 40002.

** Department of Biomedical Sciences, College of Veterinary Medicine, Oregon State University, Corvallis, OR, 97331, USA.

Supported in part by grants from the Willamette Valley Llama Foundation, Oregon State University, College of Veterinary Medicine unrestricted funds, and the Cell and Tissue Analysis Facilities and Services Core facility of the Environmental Health Sciences Center, Oregon State University, USA.
} 
College of Veterinary Medicine at Oregon State University were added to the gross anatomic study. These adult llamas ( 21 females and 4 males) ranged in age from 2 to 18 years (mean 6.5 years) and weight from $98.2-186.4 \mathrm{~kg}$; mean weight $147.3 \mathrm{~kg}$. The Institutional Animal Care and Use Committee approved housing of the animals and the research protocol.

Gross Anatomy. The llamas were humanely killed with intravenous pentobarbitol (Beuthanasia-D Special, ScheringPlough Animal Health Corp, Union, NJ) at $0.45 \mathrm{ml} / \mathrm{kg}$ body weight and laid in right lateral recumbency. The esophagus was exposed and the course was observed along the entire length. The cervical, thoracic, abdominal and total lengths of the esophagus were measured in situ. Cervical esophageal length was defined from the initial entrance of the esophagus into the neck to the flexure at the thoracic inlet (between the first ribs). Thoracic esophageal length was defined from the thoracic inlet to the diaphragm. The distance from the diaphragm to the expansion of the wall of the first compartment $(\mathrm{C} 1)$ of the stomach was measured for length of the abdominal esophagus. The outer diameter of the esophagus was measured in situ at five levels: (1) cranial cervical, (2) middle cervical, (3) thoracic inlet, (4) middle thoracic, and (5) caudal thoracic. Cranial cervical was the initial esophagus in the neck; middle cervical the halfway point between cranial cervical and the thoracic inlet. The thoracic inlet was defined as between the first ribs, caudal thoracic just prior to the diaphragm, and middle thoracic halfway between the thoracic inlet and caudal thoracic. Each level was then marked and the esophagus removed intact from the body.

Microscopic Anatomy. A complete cross-section, approximately $5 \mathrm{~cm}$ in length, was taken from the esophagus at each level and placed in 10\% buffered formalin. Each sample was trimmed, and processed for routine light microscopy with hematoxylin and eosin staining. Each crosssection was examined and the microanatomy described. The thickness of the tunica muscularis was measured in $\mathrm{mm}$ at four positions with a $90^{\circ}$ separation using a calibrated ocular micrometer and an average thickness calculated. Lobules of submucosal glands, defined as clusters of glands completely surrounded by connective tissue, were counted at each level in the entire cross-section.

Muscle Histochemistry. A specimen, approximately $1.5 \mathrm{x}$ $1.5 \mathrm{~cm}^{2}$, was removed from each defined region of the esophagus. The specimen was transferred to gauze moistened with cold saline solution and held in a Petri dish on ice prior to freezing. The specimen was trimmed and the mucosa removed. The specimen was viewed with a dissecting microscope to determine the orientation of muscle fibers and to ensure preparation of transverse sections. The specimen was mounted on a labeled cork disc with viscous embedding compound (OCT, Tissue Tek, Elkhart, IN) and rapidly frozen in isopentane cooled with liquid nitrogen. Specimens were stored at $-70{ }^{\circ} \mathrm{C}$ until sectioning. A sample of quadriceps muscles was processed in the same manner for use as a control. Sectioning of muscle was carried out in a cryostat at $19{ }^{\circ} \mathrm{C}$. At least 5 serial, $8 \mu \mathrm{m}$ thick transverse muscle fiber sections were cut. Sections were stained with Gomori trichrome and H\&E to evaluate tissue orientation and general appearance of muscle fibers. For qualitative myofibrillar histochemistry, sections were stained for myosin ATPase activity using standard methods with pre-incubation at $\mathrm{pH}$ 10.0, 4.65 and 4.35 (Dubowitz \& Brooke, 1973). The sections were examined visually by light microscopy for high, intermediate, and low enzyme activity as judged by the intensity of intracellular staining. Muscle type was determined by matching the observed enzyme activity to the profile of muscle types in quadriceps muscles. Serial sections were photographed with a digital camera attached to the microscope. Type 1 and Type 2 fibers were identified by the myosin ATPase reaction after reincubation at $\mathrm{pH} 10.0$ and type $2 \mathrm{~A}, 2 \mathrm{~B}$, and $2 \mathrm{C}$ fibers were identified by the myosin ATPase reaction after preincubation at $\mathrm{pH} 4.65$ and $\mathrm{pH} 4.35$ 9 (Brooke \& Kaiser, 1970). Fiber type proportions were determined using color micrographs of serial sections with 100 randomly selected fibers counted at each esophageal level.

Statistical Analysis. Quantitative data was evaluated and all values are expressed as mean \pm SD. The repeated measures ANOVA with Tukey's Studentized Range (HSD) test for multiple comparisons of means was used for comparisons of quantitative data at all levels of the esophagus (SAS for Windows, Version 8, SAS Institute Inc, Cary, NC). A twotailed significance criterion was set at $\mathrm{p}=0.05$.

\section{RESULTS}

Gross Anatomy. The cervical esophagus lay dorsal and slightly to the left of the trachea. As the esophagus passed through the thoracic inlet it lay dorsal to the trachea. Within the mediastinum, the thoracic esophagus crossed to the right of the aortic arch dorsal to the heart base. In adult llamas the esophagus was approximately $121 \mathrm{~cm}$ long, with the cervical portion being approximately $80 \mathrm{~cm}$ long, and the thoracic portion approximately $40 \mathrm{~cm}$ long (Table I). The abdominal portion of the llama esophagus was very short, approximately $2 \mathrm{~cm}$ long, placing the cardia of $\mathrm{C} 1$ of the stomach in close contact with the diaphragm. Esophageal outer diameter began in the cervical portion at $2.5 \mathrm{~cm}$ and gradually enlarged 
throughout the length to 3.9 at the caudal thorax (Table I).

Microscopic Anatomy. The llama esophagus consisted of four layers: (1) mucosa, (2) submucosa, (3) muscularis, and (4) adventitia (serosa) (Figure 1). The mucosal epithelium was a keratinized, stratified squamous epithelium throughout the length of the esophagus. The stratum corneum of the epithelium was composed of approximately 7-10 cell layers. Cells at the surface lacked nuclei. The lamina propria consisted of connective tissue, vascular structures, and scattered lymphocytes; submucosal ganglia were not noted. Finger-like extensions of lamina propria, the papillary layer, interdigitated with the epithelium. The muscularis mucosa, identifiable only in the most distal esophagus, consisted of a few, thin, scattered strands of smooth muscle. Submucosal glands were abundant and found throughout the length of the esophagus. The glands, however, were less numerous towards the caudal end of the esophagus; the number of lobules of submucosal glands found in each region of the esophagus ranged from 42 in cross-sections of the cranial cervical region to 31 in the middle thoracic region (Table II). The glands were ovoid or elliptical, and composed of large and small clusters or lobules of tubuloalveolar mucous glands (Figure 1). In each cross-section throughout the esophagus, the glands were equally distributed around the circumference of the wall. Submucosal glands abruptly disappeared in the cardia. The tunica muscularis was composed of striated muscle throughout the length of the esophagus. The thickness of the tunica muscularis in the thoracic segment was greater than that of the cervical segment (Table II). The tunica muscularis consisted of two layers, the inner and the outer layers. In general, fibers of the outer tunic were circularly arranged. But, inspection of the entire cross-section of the specimens revealed areas in both tunics in which an admixture of longitudinally and circularly arranged fibers was present. In transverse frozen sections, muscle fibers were smaller in diameter and less polygonal than those in limb muscle. A slight variation in muscle fiber size was found in the distal segment of the esophagus. Blood vessel and perimysial connective tissue density increased in the tunica muscularis of the distal segment of the esophagus. Nerve fibers were seen between two layers of the tunica muscularis and within each layer itself. Myenteric ganglion cells were not readily seen except in 5 of 45 sections that were carefully examined in which 1-3 ganglion cell bodies, identifiable nuclei, were found. In some sections nerve fibers extending from the tunica adventitia into the tunica muscularis were observed.

Muscle histochemistry. The myosin ATPase reaction readily differentiated Type 1 and Type 2 fibers in esophageal musculature and in control quadriceps muscle. Reversal of fiber type staining was achieved after preincubation at $\mathrm{pH}$ 4.35 (Figure 2). Type 2 fibers in the quadriceps were a uniform population, with no distinction between $2 \mathrm{~A}$ and $2 \mathrm{~B}$ fibers. A more variable staining was seen in esophageal muscle, but identification of the various subtypes of Type 2 fibers was not possible with the methodology employed. Type 2 fibers predominated in both the cervical segment $(99 \%)$ and the thoracic segment $(65 \%)$ of the esophagus (Figure 2). There was a gradual increase in Type 1 fibers from the cranial $(1 \%)$ to the caudal segment $(35 \%)$ of the esophagus. Specifically, the percentages of Type 1 fibers in the segments were: cranial cervical $1 \pm 1$, middle cervical $4 \pm 2$, thoracic inlet $7 \pm 3$, middle thoracic $16 \pm 5$, caudal thoracic $35 \pm 6$.

Table I. The length and outer diameter of the llama esophagus. a,b,c,d Means with different superscripts are significantly different in esophageal diameter between regions $(\mathrm{P} \leq 0.05)$.

\begin{tabular}{lllc}
\hline Esophageal segment & Length $(\mathbf{c m})$ & Esophageal region & Esophageal diameter $(\mathbf{c m})$ \\
\hline Cervical & $80.00 \pm 4.49$ & Cranial cervical & $2.54 \pm 0.31^{\mathrm{a}}$ \\
& & Middle cervical & $2.62 \pm 0.23^{\mathrm{a}}$ \\
Thoracic & $41.76 \pm 3.69$ & Thoracic inlet & $2.99 \pm 0.38^{\mathrm{b}}$ \\
& & Middle thoracic & $3.50 \pm 0.62^{\mathrm{c}}$ \\
Total length & $121.76 \pm 6.63$ & Caudal thoracic & $3.89 \pm 0.77^{\mathrm{d}}$ \\
\hline
\end{tabular}

Table II. The thickness of tunica muscularis and the number of lobules of submucosal glands in each region of the llama esophagus. a,b,c Within columns means with different superscript letters are significantly different $(\mathrm{P} \leq 0.05)$.

\begin{tabular}{lcc}
\hline Esophageal region & $\begin{array}{c}\text { Thickness of tunica } \\
\text { muscularis }(\mathbf{m m})\end{array}$ & $\begin{array}{c}\text { Number of lobules of submucousal } \\
\text { glands per cross section }\end{array}$ \\
\hline Cranial cervical & $3.43 \pm 0.30^{\mathrm{a}}$ & $42 \pm 4^{\mathrm{a}}$ \\
Middle cervic & $3.60 \pm 0.45^{\mathrm{a}, \mathrm{b}}$ & $36 \pm 5^{\mathrm{a}, \mathrm{b}}$ \\
Thoracic inlet & $3.98 \pm 0.47^{\mathrm{b}, \mathrm{c}}$ & $34 \pm 4^{\mathrm{b}, \mathrm{c}}$ \\
Middle thoracic & $4.39 \pm 0.39^{\mathrm{c}}$ & $31 \pm 6^{\mathrm{c}}$ \\
\hline
\end{tabular}




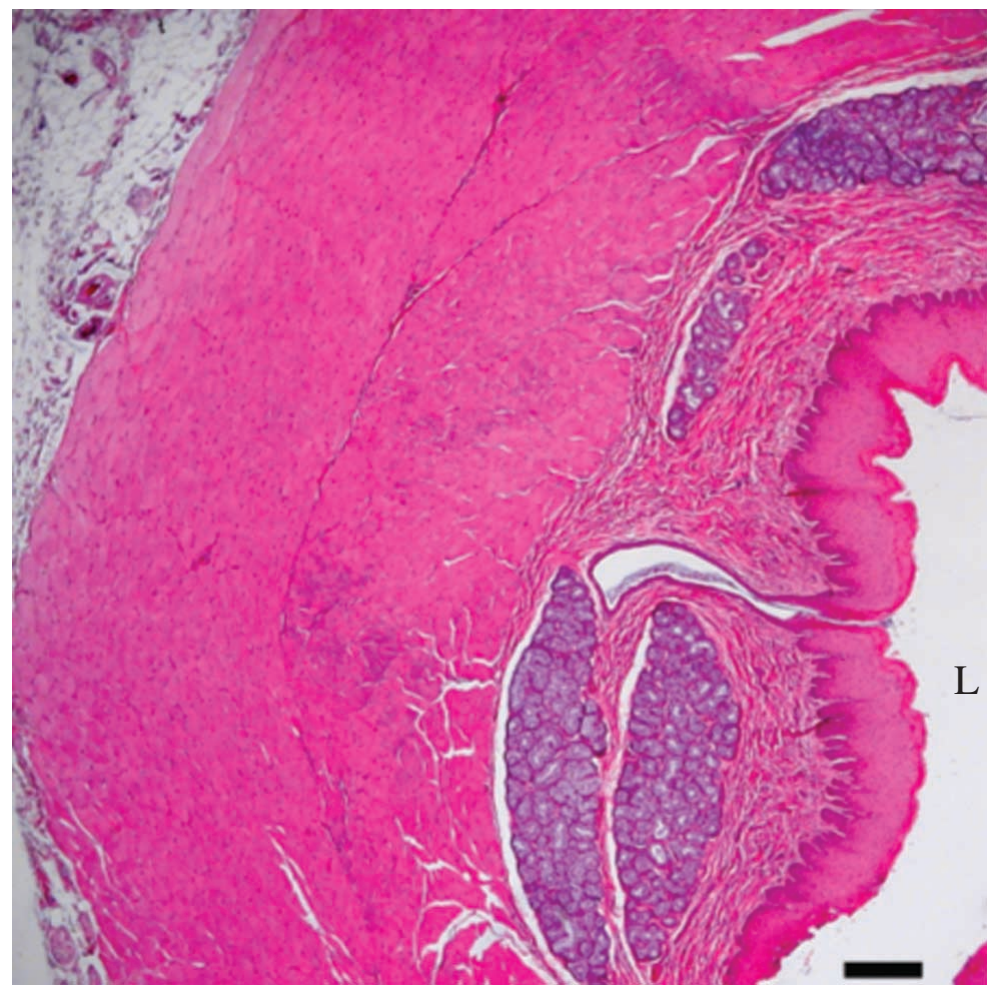

\section{Cervical esophagus}
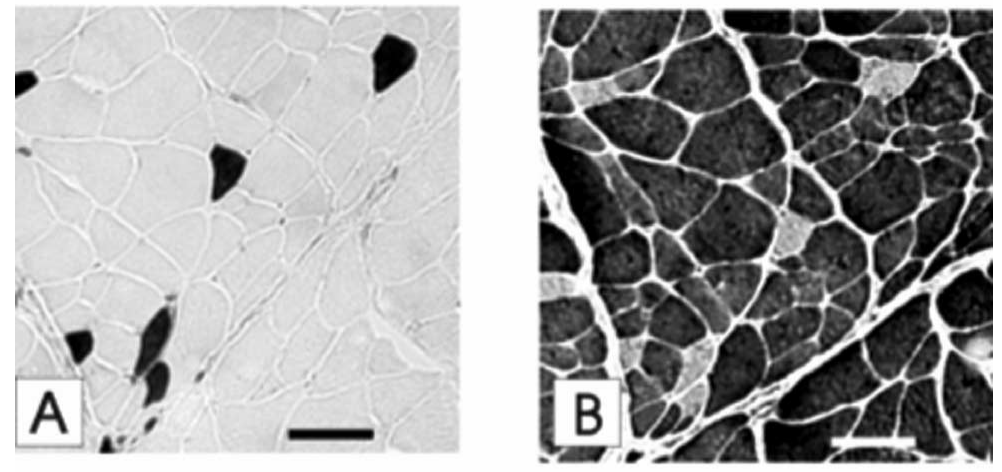

\section{Thoracic esophagus}

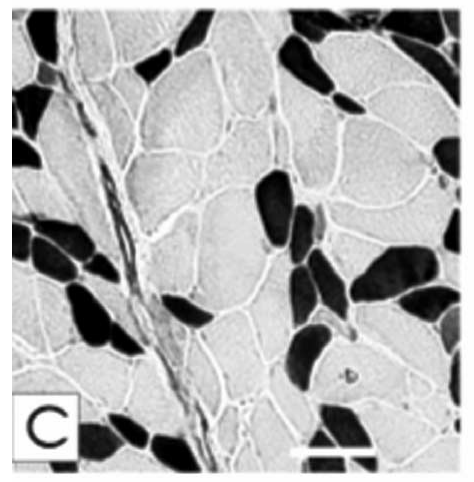

pH 4.35

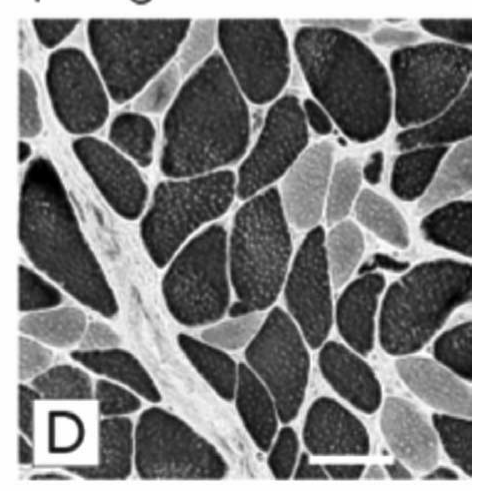

$\mathrm{pH} 10$
Fig. 1. A portion of a typical cross-section of the llama esophagus. The mucosal epithelium (E) is keratinized stratified squamous. The exocrine submucosal glands (G) are abundant with ducts (black arrow) to transport their products to the epithelial surface. The tunica muscularis $(\mathrm{M})$ consists of the two striated muscle layers with a high degree of mixed fiber orientation, separated by sparse connective tissue bands containing small blood vessels and nerves. The adventitia is prominent. (L) indicates the lumen of the esophagus. H\&E staining, bar $=150 \mu \mathrm{m}$

Fig. 2. Myosin ATPase stained sections of the llama esophageal muscle. Type 1 muscle fibers are light staining at $\mathrm{pH} 10.0$ and stain darkly at $\mathrm{pH} 4.35$. The reverse is true for type 2 muscle fibers. Type 2 muscle fibers are the predominant type in both cervical and thoracic portions of the esophagus. The proportion of type 1 muscle fibers is low in the cervical esophagus and increases in the thoracic esophagus. Bar $=50 \mu \mathrm{m}$. A: middle cervical esophagus, llama; frozen section, myofibrillar ATPase reaction $\mathrm{pH}$ 4.35. B: middle cervical esophagus; frozen section, myofibrillar ATPase reaction $\mathrm{pH}$ 10.0. C: caudal thoracic esophagus; frozen section, myofibrillar ATPase reaction $\mathrm{pH}$ 4.35. D: caudal thoracic esophagus; frozen section, myofibrillar ATPase reaction $\mathrm{pH} 10.0$. 


\section{DISCUSSION}

The length of the cervical portion of the llama esophagus is approximately twice that of the thoracic portion, in keeping with the long neck of the llama. In this group those slightly larger animals with longer necks would obviously be the animals with the longer esophagus. Though there was a large range in body weights among the study group this was due much more to a range in body condition (from 3 to 10 out of 10 , with 5 being the optimum) than to a large variation in body size. Unfortunately height of these llamas was not measured which would have been a preferable measurement of size of the llamas. Adult height at the withers is reached at 18 months and varies far less than body weight (Smith et al., 1992). Males and females could be considered together as there is not sexual dimorphism in adult size in llamas (Smith et al.).

The outer diameter of the llama esophagus, like that of the cow and sheep, significantly increases from the cranial portion to the caudal portion. The esophageal diameter in the llama $(2.5 \mathrm{~cm}$ in the cranial cervical portion to $3.9 \mathrm{~cm}$ in the caudal thoracic portion) is smaller than that of the cow ( $3 \mathrm{~cm}$ in the neck to $4 \mathrm{~cm}$ wide and $7 \mathrm{~cm}$ high in the caudal thorax)(Schummer et al., 1979) but is bigger than that of the sheep ( $1.8 \mathrm{~cm}$ at the pharynx to $2.5 \mathrm{~cm}$ at the cardia) (Getty, 1975 ) in agreement with the overall body size of the llama between cattle and sheep. The increasing thickness of the tunica muscularis through the llama esophagus is similar to the horse in which the thickness of the tunica muscularis increases from the middle cervical region $(3 \mathrm{~mm})$ to the middle thoracic esophagus (4.2 mm) (Slocombe et al., 1982), but differs from the cow in which the tunica muscularis is thicker in the cervical part $(4-5 \mathrm{~mm})$ and thinner in the thoracic part (2-3 $\mathrm{mm}$ ) (Schummer et al.). This difference could be due to the differences in the relative position of the neck and in natural grazing and swallowing behavior between these species. The neck of the llama is much more upright than that of the cow. In the llama, in addition to esophageal peristalsis, gravity allows for easier passage of a bolus of food in the cervical esophagus when the head is upright. Without the assistance of gravity, the horizontal thoracic esophagus may require stronger muscular activity to move the bolus of food, thus the increase in muscle mass.

The thick heavily keratinized mucousal epithelium of the llama esophagus is similar to the camel, cow, sheep, horse, and rodent, but differs from the human, monkey, dog, and cat esophagus (DeNardi \& Riddell, 1991; Fawcett \& Raviola, 1994; Schummer et al.). This thick keratinization of the epithelium helps to prevent injury from ingestion of coarse and dry foods, the natural food source of the llama in the high Andean region. The presence of the muscularis mucosa in the form of a few scattered strands of smooth muscle, only in the caudal segment of the llama esophagus, is similar to the camel (Jamdar \& Ema), but is contrary to what is found in the ruminants. In the latter, the muscularis mucosa occurs through the length of the esophagus, although it is discontinuous (Schummer et al.). The presence of abundant submucosal glands throughout the length of the llama esophagus is similar to that of the camel (Jamdar \& Ema). In ruminants, horses, and cats, the submucosal glands are found only in the pharyngo-esophageal region (Schummer et al.). Both camels and llamas evolved in a coarse forage environment, and mucous glandular secretion aids in the passage of this forage through the long esophagus. The secretions of these glands may also contribute to the increased buffering capacity of $\mathrm{C} 1$ of the llama compared to rumen of the true ruminants resulting in increased absorption of volatile fatty acids in the llama stomach compared to the rumen of sheep and cattle (Vallenas et al., 1973).

The esophageal tunica muscularis in most species can be divided into two layers: the inner and the outer. The proportion of striated and smooth muscle varies greatly among species. In the horse, the tunica muscularis of the cranial two-thirds of the esophagus consists of striated muscle, and the caudal third is of smooth muscle (Schummer et al.). In the ruminant, and camel, the tunica muscularis consists entirely of striated muscle (Goetsch, 1910; Schummer et al.; Jamdar \& Ema). The orientation of muscle fibers also varies among species. In the horse, the striated muscle layers are oriented obliquely to one another; the muscular layers become oriented in more of an inner circular and outer longitudinal configuration in the caudal esophagus (Schummer et al.). In the ruminant, and camel, the orientation of the striated muscle fibers in the inner and outer layers of the tunica muscularis is mixed, oblique, and spiral (Getty; Jamdar \& Ema). As expected, the two-layered skeletal muscle tunica muscularis with a high degree of mixed fiber orientation in both the outer and inner layers of the llama esophagus is similar to the ruminant and most similar to the camel.

The myenteric plexus is present in the esophagus of most species but its distribution and prominence varies greatly. In cattle, the myenteric plexus is composed of differently shaped ganglia and interconnecting nerve fiber strands. From the cervical toward the thoracic segment of the esophagus the density and size of myenteric ganglia increase and nerve fiber strands exhibit thicker diameters (Teixeira et al., 2001; Vittoria et al., 2000). The myenteric 
plexus in the llama is similar to that in the camel in that it is scant and difficult to locate (Jamdar \& Ema). The function of the myenteric plexus in striated esophageal muscle is still unclear, but recent studies have shown co-innervation between the nerve fibers from the vagus and the plexus on the endplates of striated muscle in the guinea-pig and rat esophagus (Neuhuber et al., 2001; Zhou et al., 1996).

The muscle fiber types in the llama esophagus are similar to those in ruminants in which, in the cranial part of the esophagus, the muscle fiber type is predominantly Type 2 (99\% in llamas, cow and sheep), and the percentage of Type 1 fibers increases in the thoracic segment (35\% in llamas, $30 \%$ in sheep, and 36\% in cows) (Mascarello et al., 1984). The differing proportions of fiber types presumably reflect differences in the physiological function between the two segments of the esophagus. In the llama secondary peristalsis occurs frequently in the thoracic esophagus after a burp and rarely in the cervical esophagus (Sukon, 2002). The Type 1, less fatigable muscle fibers, could be important for the frequent occurrence of secondary peristalsis in the thoracic esophagus.

Anatomically, the esophagus of the llama is very similar to that of the camel. This study provides the first detailed anatomic description of the esophagus of the llama, and can be used as a basis for further studies of esophageal malfunction (megaesophagus as an example) in this species.

\section{ACKNOWLEDGEMENTS}

The authors thank Ms. Nancy Hollingshead, Kay Fischer and Mr. Mehmet Kupeli of the College of Veterinary Medicine, Oregon State University for their assistance with this project.

SUKON, P.; TIMM, K. I. \& VALENTINE, B. A. Anatomía del esófago de la Llama (Lama glama). Int. J. Morphol., 27(3):811-817, 2009.

RESUMEN: Este estudio describe la anatomía morfológica, microscópica, y tipo de fibra muscular del esófago de la llama, Lama glama. Estudiamos la anatomía morfológica del esófago, con fisiología normal, en 25 llamas adultas y, adicionalmente, en 10 de ellas la anatomía microscópica. La longitud del esófago fue $122 \pm 7 \mathrm{~cm}$ con dos tercios en el cuello y un tercio en el tórax. El diámetro del esófago aumentó de 2,5 \pm 0,3 cm en la región craneal del cuello y a 3,9 \pm 0,8 cm en la región caudal del tórax. El epitelio de la mucosa eera escamoso estratificado queratinizado y la submucosa contenía abundantes glándulas a lo largo de todo el esófago. La muscular entera del esófago se compuso de músculo esquelético en más o menos dos capas, pero con algunas fibras orientadas al azar. La muscular aumentó de 3,43 \pm 0,30 $\mathrm{mm}$ en la región craneal del cuello a 4,39 \pm 0,39 $\mathrm{mm}$ en la región media del tórax. Fibras musculares Tipo 2 predominaron en la muscular. El porcentaje de fibras Tipo 1 aumentó de $1 \%$ al inicio del esófago a 33\% en la región caudal torácica. Este estudio del esófago normal de la llama ofrece más información sobre la anatomía de la llama y proporciona una base para futuros estudios de patologías esofágicas.

PALABRAS CLAVE: Llama; Esófago; Anatomía; Histología; Tipo de fibra muscular.

\section{REFERENCES}

Belknap, E. B. Medical problems of llamas. In: The Vet. Cl. of N. Amer., Food Animal Practice, Update on Llama Medicine. Johnson, L. W. (Editor). Philadelphia, W. B. Saunders Co., 1994.

Brooke, M. H. \& Kaiser, K. K. Muscle fiber type: how many and what kind? Arch. Neurol., 23:369-79, 1970.

Butt, T. D.; MacDonald, D. G. \& Crawford, W. H. Persistent right aortic arch in a mature llama. Vet. Rec., 148:118-9, 2001.

Dellmann, H. D.; Blin, P. C. \& Fahmy, M. F. A. Contribution à 1 étude de 1 anatomie microscopique du tube digestif chez le Chameau. Rev. Elev. Méd. Vét. Pays Trop., 21(1):1-32, 1968.
DeNardi, F. G. \& Riddell, R. H. The normal esophagus. Am. J. Surg. Pathol., 15:296-309, 1991.

Dubowitz, V. \& Brooke, M. H. Muscle Biopsy: a Modern Approach. London, W.B. Saunders, 1973.

Fawcett, D. W. \& Raviola, E. The esophagus and stomach. In: Fawcett, D. W. (Ed). A Textbook of Histology. $12^{\text {th }}$ ed. New York, Chapman \& Hall, 1994. pp.593-616.

Getty, R. Digestive system of the sheep. In: Sissona Grossman's The Anatomy of Domestic Animals. $5^{\text {th }} \mathrm{Ed}$. Philadelphia, W. B. Saunders Co., 1975. pp.477-84.

Goetsch, E. The structure of the mammalian esophagus. Am. J. Anat., 10:1-40, 1910. 
Jamdar, M. N. \& Ema, A. N. The submucosal glands and the orientation of the musculature in the oesophagus of the camel. J. Anat., 135:165-71, 1982.

Mascarello, F.; Rowlerson, A. \& Scapolo, P.A. The fibre type composition of the striated muscle of the esophagus in ruminants and carnivores. Histochemistry, 80:277-88, 1984.

Neuhuber, W. L.; Eichhorn, U. \& Worl, J. Enteric coinnervation of striated muscle fibers of the esophagus: just a "hangover"? Anat. Rec., 262(1):41-6, 2001.

Schummer, A.; Nickel, R. \& Sack, W. O. The alimentary canal. In: The Viscera of Domestic Mammals. New York, Springer-Verlag, 1979. pp.99-202.

Slocombe, R. F.; Todhunter, R. J. \& Stick, J. A. Quantitative ultrastructural anatomy of esophagus in different regions in the horse; effects of alternate methods of tissue processing. Am. J. Vet. Res., 43:1137-42, 1982.

Smith, B. B.; Timm, K. I. \& Reed, P. J. Morphometric evaluation of growth in llamas (Lama glama) from birth to maturity. Am. J. Vet. Med. Assoc., 200:1095-100, 1992.

Smith, J. A. Noninfectious, metabolic, toxic and neoplastic diseases of Camelids. In: The Vet. Cl. Of N. Amer., Food Animal Practice, Llama Medicine. Johnson, L. W. (Ed.). Phildelphia, W.B. Saunders Co., 1989. pp.103-4.

Smuts, M. M. S. \& Bezuidenhout, A. J. Anatomy of the Dromedary. Oxford, Clarendon Press, 1987. pp.119-23.

Sukon, P. The Physiology and Anatomy of the Esophagus of Normal Llamas and Llamas with Megaesophagus. $\mathrm{PhD}$ Thesis, Oregon State University, Corvallis, OR, 2002. p.77.

Teixeira, A. F.; Vives, P.; Krammer, H. J.; Kühner, W. \& Wedel, T. Structural organization of the enteric nervous system in the cattle esophagus revealed by wholemount immunohistochemistry. Ital. J. Anat. Embryol., 106(2):313-21, 2001.

Vallenas, A.; Cummings, J. F. \& Munnell, J. F. A gross study of the compartmentalized stomach of two new-world camelids, the llama and guanaco. J. Morph., 134:399424, 1971.

Vallenas, A.; Llerena, L.; Valenzuela, A.; Chauca, D.; Esquerre, J. \& Candela, E. Concentración de acidos grasos volatiles a lo largo del tracto gastrointestinal de alpacas y llamas (Volatile fatty acid concentrations in the length of the gastrointestinal tract of alpacas and llamas). Rev. Inv. Pec. (IVITA), 2(1):3-14, 1973.

Vittoria, A.; Costagliola, A.; Carrese, E.; Mayer, B. \& Cecio, A. Nitric oxide-containing neurons in the bovine gut, with special reference to their relationship with VIP and galanin. Arch. Histol. Cytol., 63:357-68, 2000.

Watrous, B. J.; Pearson, E. G.; Smith, B. B.; Snyder, S. P.; Blythe, L. L.; Riebold,T. W. \& Hedstrom, O. R. Megaesophagus in 15 llamas: a retrospective study (1985-1993). J. Vet. Intern. Med., 9:92-9, 1995.

Zhou, D. S.; Desaki, J. \& Komuro, T. Neuromuscular junctions of longitudinal and circular muscle fibers of the guinea-pig esophagus and their relation to myenteric plexus. J. Auton. Nerv. Syst., 58:63-8, 1996.

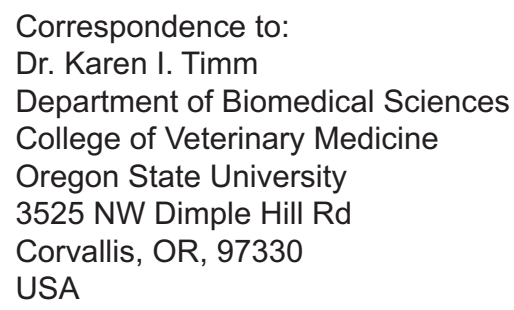

Email: Karen.Timm@oregonstate.edu

Received: 22-04-2009

Accepted: 15-07-2009 
